\title{
Geriatrisen kuntoutusosaston omahoitajat työnsä kehittäjinä
}

Artikkelissa kuvataan erään lonkkamurtumapotilaisiin keskittyneen geriatrisen kuntoutusosaston tutkimus- ja kehittämishankkeen tuloksia. Hanke käynnistyi hoitajien aloitteesta, ja sen tavoite oli omahoitajien työkäytänteiden kehittäminen potilaan kotiutusprosessin sujuvoittamiseksi. Näin toivottiin vähennettävän työn kuormitusta ja vahvistettavan hoitajien kokemaa työhyvinvointia. Hankkeen tutkimus- ja kehittämistoiminta tapahtui työelämän tutkimusavusteisena kehittämisenä dialogisin menetelmin työpajatyöskentelynä. Kehittämisen työpajojen yhteydessä kerätty haastatteluaineisto analysoitiin induktiivisella sisällönanalyysillä. Analyysin pohjalta saatiin käsitteellinen ymmärrys työn haasteista ja kehittämisehdotukset työn sujuvoittamiseksi. Käsitteellisen ymmärryksen pohjalta luotiin kaksi kertomusta, joista ensimmäinen kuvaa työn haasteita ja toinen ratkaisuehdotuksia työkäytäntöjen kehittämiseksi. Tulokset osoittavat, että moniammatillisen tiimin jäsenten vastuita kotiutusprosessissa tulisi selkeyttää. Samoin moniammatillisen tiimin kirjaamiskäytäntöjä koskevaa viestintää tulee kehittää. Selkeät vastuut moniammatillisen tiimin toiminnassa ja viestinnän toimivuus antavat omahoitajille mahdollisuuden keskittyä yhä paremmin hoitotyöhön. Näin he myös kokevat työnsä mielekkääksi.

Asiasanat: työn kehittäminen, omahoitajat, moniammatillisuus, narratiivisuus

Aikuiskasvatus 39 (1), 6

\section{Named primary nurses of a geriatric rehabilitation ward as developers of their own work}

This article describes the results of a research and development project carried out in a geriatric rehabilitation ward treating hip fracture patients. The $R \& D$ project was initiated by the primary nurses themselves, with the objective of improving work practices to improve the patients' discharge procedures. Desired outcomes were decreasing the stressfulness of work and strengthening work wellbeing. Workshopbased dialogical methods were used to carry out the research-assisted working life improvement as part of the project activities. These development workshops yielded interview data which was analysed using inductive content analysis. The analysis offered a conceptual understanding of the challenges of the work and suggestions for development. This conceptual understanding served as a foundation for two narratives, the first of which describes the challenges of the care work. The second narrative describes solution suggestions aiming at improving work practices. The results point to a need to clarify the allocation of responsibilities in a multiprofessional team in the discharge process. There is a similar need for clarification regarding communication about recording and filing practices. Clear responsibilities and communication enable named primary nurses s to better focus on care work. This in turn creates a sense of purpose in the work.

Keywords: improvement of work, named primary nurses, multiprofessionalism, narrative

Aikuiskasvatus 39 (1), 6 


\section{Alanvaihto ja ammatillisen identiteetin muutos ruumiillisina tiloina ja tuntemuksina}

Artikkelissa hahmotellaan aikuisten opettajaopiskelijoiden yksilöllisten tuntemusten kautta affektiivisia tiloja, tunnesävyjä, jotka kuvaavat ammatillisen identiteetin muuttumista alanvaihdossa ja kouluttautumisessa uudelle alalle. Artikkeli nojaa työelämän ruumiillisuuden monitieteiseen tutkimusperinteeseen ja affektiiviseen käänteeseen, jonka myötä tuntemusten tutkimus on lisääntynyt. Tutkimuksen aineisto koottiin haastattelemalla kolmea alanvaihtajaa, joilla oli aiempi korkeakoulututkinto ja ammatillinen identiteetti toiselta alalta. Lähestymistapa analyysiin oli narratiivinen, ja menetelmänä hyödynnettiin odotusanalyysiä. Alanvaihto jäsentyi kolmeksi affektiiviseksi tilaksi, jotka ovat aikaisemmasta ammatillisesta identiteetistä irtoaminen, välitilaa koskevan puhdistuminen sekä uuden ja erilaisen tulollaan oleminen. Prosessi näyttäytyi yhtäältä raskaana ja yksinäisenä identiteettityön puurtamisena. Toisaalta tutkimuksen haastateltavat näyttivät aidosti löytävän itseään uuden koulutuksen avulla.

Asiasanat: ruumiillisuus, affektiivisuus, ammatillinen identiteetti, alanvaihto

Aikuiskasvatus 39 (1), 19

\section{Career and professional identity change as embodied states and affects}

This article delineates affective states and nuances of adult teacher students prompted by career change and a new professional education. The article leans on the multidisciplinary research tradition of the body in working life and the Affective Turn, which has increased research on affects. The data were gathered by interviewing three career changers who had a previous university degree and a professional identity in that field. Narrative methods, specifically expectation analysis, were used. Career change presented itself as three distinct affective states, namely detaching from the previous professional identity, a regenerating intermediate state between identities, and a state of becoming of something new and different. A hard and lonely process of arduous identity work was witnessed. However, the interviewees clearly were on a path of self-discovery through the new education.

Keywords: body, affect, professional identity, career change

Aikuiskasvatus 39 (1), 19 


\section{Vertaisuuden tunnustaminen esimiesorientaationa - Verme-koulutus jaettua johtajuutta kehittämässä}

Artikkelissa tutkitaan vertaisuuden tunnustamista esimies-työntekijäsuhteessa vertaisryhmämentorointi- eli verme-koulutuksessa, jossa tehtäviinsä nimitetyt päälliköt hakivat uutta orientaatiota esimiestyöhönsä. Vallitsevat käsitykset johtamisesta organisaatioissa perustuvat vähintäänkin implisiittiselle toimijoiden ja heidän positioidensa eritasoisuudelle. Tarkastelemme päällikön ja työntekijän uudenlaisen suhteen rakentumista Georg Wilhelm Friedrich Hegelin 'tunnustuksen' käsitteen lähtökohdasta. Empiirinen materiaali on toteuttamastamme verme-koulutuksesta, jossa vertaistyöskentelyä ryhmissä haettiin myös johtami- sen orientaatioksi. Aineisto hankittiin koulutuksessa käytetyistä tehtävistä, keskusteluista, niiden lähiluvusta ja keskinäisistä reflektioistamme. Vertaisuus ja siihen kuuluva tunnustuksen periaate tarjoavat uuden työn ja personoitumisen kontekstissa näkökulman sekä johtamiskoulutukseen että jaetun johtamisen orientaatioon.

Asiasanat: vertaisryhmämentorointi, verme, vertaisuus, tunnustus, jaettu johtajuus, esimieskoulutus

Aikuiskasvatus 39 (1), 36

HEIKKI PASANEN \& MERJA ALANKO-TURUNEN

\section{Recognising peerness as a leadership orientation - peer group mentoring in the development of shared leadership}

This article studies the recognition of peerness, especially epistemic peerhood in a manager-employee relationship in a peer group mentoring model, in a situation, where newly appointed mangers were reorientating themselves to their managerial duties. Current understanding on organizational management is based on a hierarchy - at the very least an implicit one - of agents and their positions. We take G. W. F. Hegel's concept of "recognition" as our starting point as we examine the emergence of a new kind of manager-employee relationship. Our empirical material stems from peer group mentoring process programme we ran ourselves. In this training we sought to use peer group mentoring as an orientation for leadership. We collected the data from training assignments, discussions and their close reading, and our mutual reflection. Peerness and its inherent principle of recognition offer a perspective both to leadership training and to shared leadership orientation in the context of new work and personification.

Keywords: peer group mentoring, peerness, epistemic peerhood, recognition, shared leadership, leadership training

Aikuiskasvatus 39 (1), 36 